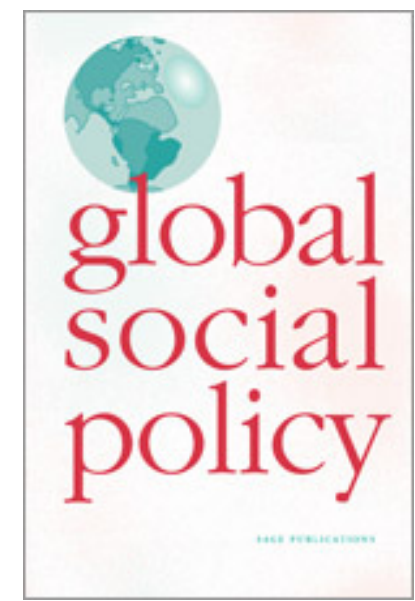

\title{
Perceived Welfare Deservingness of Needy People in Transition Countries: Comparative Evidence from the Life- in-Transition Survey 2016
}

\begin{tabular}{|c|l|}
\hline Journal: & Global Social Policy \\
\hline Manuscript ID & GSP-20-0055.R1 \\
\hline Keywords: & $\begin{array}{l}\text { Transition countries, welfare, deservingness, social protection, cross- } \\
\text { national analysis, Life-in-Transition Survey }\end{array}$ \\
\hline Abstract: & $\begin{array}{l}\text { Transition to the market economy and the related restructuring of } \\
\text { welfare systems has produced new vulnerabilities in the formerly } \\
\text { communist countries of Eastern Europe and Central Asia, while } \\
\text { simultaneously aggravating the existing ones. Given the limited fiscal } \\
\text { capacities of the transition countries, this brings to the fore the issue of } \\
\text { which of the new and old vulnerable groups of people are considered to } \\
\text { be deserving of public support. Using data from the third round of the } \\
\text { Life-in-Transition survey (2016), this paper explores the perceived } \\
\text { welfare deservingness of five groups: the elderly, the disabled, the } \\
\text { unemployed, the working poor and families with children. We find that } \\
\text { with some exceptions, the hierarchy of deservingness of these groups is } \\
\text { similar to that systematically identified in Western welfare states. } \\
\text { However, there is also a large variation in the deservingness levels } \\
\text { across countries, some of which appear to be related to the differences } \\
\text { in the levels of economic development. We also find that in transition } \\
\text { countries, individual self-interest and ideological predispositions largely } \\
\text { have the same effects on people's deservingness perceptions as those } \\
\text { found in Western welfare states in previous studies. }\end{array}$ \\
\hline
\end{tabular}

\section{SCHOLARONE" \\ Manuscripts}




\title{
Perceived Welfare Deservingness of Needy People in Transition Countries: Comparative Evidence from the Life-in-Transition Survey 2016
}

\begin{abstract}
Transition to the market economy and the related restructuring of welfare systems has produced new vulnerabilities in the formerly communist countries of Eastern Europe and Central Asia, while simultaneously aggravating the existing ones. Given the limited fiscal capacities of the transition countries, this brings to the fore the issue of which of the new and old vulnerable groups of people are considered to be deserving of public support. Using data from the third round of the Life-in-Transition survey (2016), this paper explores the perceived welfare deservingness of five groups: the elderly, the disabled, the unemployed, the working poor and families with children. We find that with some exceptions, the hierarchy of deservingness of these groups is similar to that systematically identified in Western welfare states. However, there is also a large variation in the deservingness levels across countries, some of which appear to be related to the differences in the levels of economic development. We also find that in transition countries, individual self-interest and ideological predispositions largely have the same effects on people's deservingness perceptions as those found in Western welfare states in previous studies.
\end{abstract}

Keywords: Transition countries, welfare, deservingness, social protection, comparative analysis 


\section{Introduction}

The transition to a market economy has resulted in two major implications for welfare provision in the formerly communist countries of Eastern Europe and Central Asia. On the one hand, the collapse of the centrally-planned economic systems has generated new vulnerabilities, most notably in relation to employment. While the presence of underemployment and latent unemployment in communist countries is widely acknowledged, almost complete formal employment meant that the majority of people received a stable income augmented by occupational benefits. Moreover, the differences in salaries were much lower than in market economies. Together with heavily subsidized consumer goods and public housing, this enabled reasonable - though far from affluent - standards of living. With economic recession and the inevitable abandonment of guaranteed employment, unemployment became a new reality. At the same time, deregulation of wage setting and the growth of informal employment produced a new group of working poor.

On the other hand, while labour market transformations placed new demands on the welfare systems, large contractions of fiscal bases further constrained their capacities to cater for the needs of their traditional clientele: elderly and disabled people and families with children. This has provided the rationale for welfare reform, which has resulted in various degrees and forms of retrenchment, whether institutional (e.g., abandoning particular types of welfare provision, reducing entitlements, introducing means-testing and co-payments), defacto (e.g., maintaining provision, but massively reducing the actual spending by not indexing benefits) or a combination of both. While most transition countries have made significant economic progress since the 2000s, and their welfare systems are now much better equipped than in the 1990s, the communist type of paternalistic, cradle-to-grave welfare system is no longer an option, bringing to the fore the issue of rationing the more-constrained welfare 
resources among the competing "traditional" and "newly emerged" groups of vulnerable people. This in turn raises the fundamental question of which social groups people in transition countries consider worthy or deserving of public welfare support, and how these deservingness perceptions are influenced by individual and contextual factors.

In the present paper, we aim to answer these questions by using the data from the Life in Transition Survey (LiT). More specifically, we analyse to what extent the variance in perceived welfare deservingness can be explained by country-level and individual-level variables commonly used in research into welfare opinions. Our analysis focuses on the popular welfare deservingness of five vulnerable groups: the elderly, the disabled, the unemployed, the working poor and families with children.

The paper is organized as follows. The second section familiarizes the readers with the context of the analysis by providing a brief overview of the communist welfare states and their evolution since the start of the transition. The third section details the theoretical framework and formulates hypotheses by drawing on literature about welfare opinions in Western welfare states. The fourth section outlines the methodology and the fifth presents the results. The concluding section summarizes and discusses the main findings.

\section{Welfare Systems in Transition Countries: Past and Present}

The communist welfare regime type originated in the Soviet Union in the 1930s, and was eventually exported to Eastern European countries in the aftermath of World War II, replacing the previous social insurance and voluntary arrangements (Cook, 2007). While bearing many similarities to Western welfare states, ${ }^{1}$ especially in terms of wide coverage

\footnotetext{
${ }^{1}$ While acknowledging large differences in how they organize public welfare provision, by the term "Western welfare states" throughout the text we refer to Western European and Anglo-Saxon
} 
and multiple cash and in-kind benefits for various groups, the communist welfare regimes possessed a number of unique characteristics (Orenstein 2008; Manning 2004; Deacon 2000; Gugushvili 2017). The most distinctive feature was nearly full employment. Practically all able-bodied citizens were guaranteed (and also obliged to take up) salaried work in state-run enterprises and collective farms. ${ }^{2}$ Communist countries also spent excessive proportions of GDP on subsidizing basic consumer goods, which enhanced the purchasing power of people on salaries that were considerably lower than in developed market economies (Cook, 2007; Fajth, 1999). A further boost to salaries came from multiple occupational benefits, such as subsidized canteens, entertainment, free hotels and sanatoriums and even housing for workers employed outside the agricultural sector (Manning, 2004). On the other hand, since the presence of unemployment and poverty were officially denied, with a few exceptions in Eastern European countries there were no unemployment benefits or social assistance for poor people (Noelke, 2008).

Furthermore, unlike Western welfare states, employees paid no or only symbolic social insurance contributions and income taxes (Noelke, 2008). Nonetheless, citizens' employment record mattered, as the number of years in employment and the final salary were factored-in when calculating the amount of old-age pensions. The type of work was also important in determining the eligibility to other benefits, as the state allocated many in-kind

countries with extensive formal social protection mechanisms that account for a large proportion of public spending.

${ }^{2}$ A notable exception to this rule was Yugoslavia, due to its unique feature of a socialist economy (Gebel, 2008). There, enterprises were owned by workers and subject to competition, thus facing tougher budget constraints. This prompted managers to avoid the overstaffing typical in other communist economies, in order to pay higher salaries to the insiders. As a result, there was a high rate of open unemployment. 
benefits to reward groups for various contributions to society, such as being a war veteran, serving in the armed forces, raising many children, teaching in remote areas and working in hazardous environments (Wengle and Rasell, 2008). One area where communist welfare regimes provided more generous support than most Western welfare states was family policy. In order to achieve the double objective of high fertility rates and high female labour force participation, communist welfare regimes spent a greater proportion of GDP on family support policies compared with Western European states (Fajth, 1999). The measures included free or heavily subsidized childcare services, generous maternity benefits, long maternity leave and often universal child benefits. By contrast, while all disabled people were entitled to disability pensions graded in line with the severity of their condition, the average wage replacement rates were relatively low and the supportive services were underdeveloped. This may reflect the states' limited interest in a group that was deemed less productive than others.

Transition to the market economy entailed major changes to the communist welfare regimes. To start with, guaranteed employment and price subsidies had to be abandoned, as they were clearly incompatible with the market economy (Noelke, 2008; Wengle and Rasell, 2008). The governments tried to cushion the impact by introducing the missing elements: unemployment benefits and social assistance transfers, and in some cases easing access to early retirement and disability pensions. In the initial years, most governments also tried to protect other entitlements. The countries that experienced less severe contraction even managed to increase the proportion of GDP allocated to welfare provision (Fajth, 1999). However, in the face of mounting fiscal pressures, all the countries had to adopt some measures for retrenchment. These usually involved reducing benefit levels, tightening eligibility criteria, abandoning some entitlements and introducing means testing and copayments for services (Cook, 2007). At the same time, most countries also sought to enhance 
the role of private provision through various means, including the introduction of mandatory funded pension schemes, outsourcing of services and monetizing in-kind benefits. In short, there has been an overall overhaul of the inherited welfare regimes with a significant reduction of the states' role in welfare provision and the individualization of social risks (Deacon, 2000; Ferge, 1997).

It should, however, be emphasized that the pace and extent of welfare retrenchment or transformation varied to a great extent across the transition countries. There are several reasons for this. First, the communist bloc - and especially the Soviet Union - was an artificial conglomerate of countries with relatively different levels of economic development, human capital, demographic structure and social needs. For example, GDP per capita in 1990 (in current international dollars) was $\$ 12,666$ in the Czech Republic, $\$ 5,191$ in Bulgaria and \$1,985 in Uzbekistan (World Bank, 2020). Within the Soviet Union, the incidence of "lessprovided families" (a Soviet euphemism for poverty) varied from 2 per cent in the Baltic republics to 44 per cent in Uzbekistan and 51 per cent in Tajikistan (Atkinson and Micklewright, 1992). Second, these gaps further widened with the divergence in economic performance. While countries such as Poland and the Czech Republic recovered from recession with relatively minor losses within two or three years, recessions lasted several years longer and led to a colossal reduction in GDP in some of the former Soviet Union republics, especially the ones that suffered from armed conflicts (Falkingham and Vlachantoni, 2010). Third, divergence in the success of democratic transition also meant that in some countries the public was more able to express their preferences through the ballot box and defend their entitlements through mobilization compared with the situation in other countries that followed authoritarian paths (Orenstein, 2008). Fourth, the economic and political situation also mediated external influences on reform. Countries with stronger economies and more-accountable governments were in a better position to resist pressure 
from international financial institutions promoting the residual welfare models. Furthermore, countries with the prospect of joining the EU had stronger incentives and some technical support to bring their welfare provisions closer to European standards (Orenstein, 2008). Lastly, there were (and continue to be) large differences in the domestic configuration of political parties, the strength of trade unions and the technical capacities of line ministries charged with designing and overseeing the reform process.

Looking at the present situation, as in the past, remarkable differences are apparent. Between 2012 to 2015, social protection spending varied from 23.4 per cent of GDP in Serbia to 5.4 per cent in Kazakhstan (ILO, 2017). While most countries have the core components of a welfare state - social insurance and social assistance schemes, labour regulations, health, education and social services - the coverage, eligibility criteria, benefit levels and public/private mix vary widely, making it impossible to identify a single post-communist welfare regime type, even within the relatively more homogenous Central and Eastern European countries (Hacker, 2009). The differences are the starkest with regard to social outcomes. Children born in Slovenia are 13 times more likely to reach the age of five (mortality rate of 2.3/1000) than children born in Azerbaijan (30.9/1000), and 19 times more likely than children born in Tajikistan (43.1/1000). Inequality in Slovenia and the Czech Republic is among the lowest in the world (Gini <.25), while Georgia and Russia have very high levels (Gini >0.4) (UNDP, 2016). The average life expectancy is 12 years longer in Slovenia (80.8 years) than in Mongolia (68.8 years) (World Bank, 2020).

While the five vulnerable groups whose deservingness is the focus of this study - the elderly, the disabled, unemployed people, families with children and the working poor - can reasonably be considered as net losers from transition, differences in economic performance, welfare models and social outcomes also imply that the effects of welfare retrenchment/transformation on their welfare will vary significantly across countries. We 
expect that together with the deservingness criteria discussed in the next section, this will influence the perceived welfare deservingness of the needy groups.

\section{Theoretical Framework of Deservingness and Research Hypotheses}

\section{Hierarchy of Welfare Deservingness}

One common finding of welfare attitudes research is that there is a certain hierarchy in the perceived deservingness of primary target groups of the welfare state (Bean and Papadakis, 1998a; Coughlin, 1980; Hills, 2002; Taylor-Gooby, 1985; van Oorschot, 2006; van Oorschot et al., 2017). Elderly, sick and disabled people are usually viewed as the most deserving groups, followed by families with children. Unemployed people, the working poor, single parents and migrants attract much less sympathy, often with only a minority considering them worthy of public support.

A comprehensive theory that explains this hierarchy is offered by van Oorschot (2006), who identifies five criteria that determine particular groups' welfare deservingness in the public's eye. The first is control: groups that cannot be blamed for their misfortunes, such as elderly and disabled people, have more support. The second is recipients' attitude: groups need to be viewed as grateful and compliant in order to attract public sympathy. The third criterion is reciprocity: groups that contribute to society in one way or another, or have done so previously, are viewed as more deserving. The fourth criterion is identity: people tend to be more willing to support those with whom they share many similarities. Lastly, the higher a group's need is, the more deserving it is considered to be.

Using this framework, van Oorschot (2006) investigated perceived welfare deservingness in a comparative cross-sectional study covering 23 European nations, including seven transition countries that are also included in our analysis. In line with his 
hypothesis, van Oorschot (2006) found that a consistent pattern exists across countries and for social categories of respondents: elderly people are viewed as the most deserving, followed closely by sick and disabled people, while migrants and the unemployed are considered to be far less deserving. Drawing on this finding, as well as the results of other comparative (Bean and Papadakis, 1998b; Coughlin, 1980; van Oorschot et al., 2017) and country case studies (Hills, 2002; Taylor-Gooby, 1985), we expect that in our pooled sample elderly and disabled people will be the most deserving, unemployed the least deserving and families with children and the working poor will occupy the middle of the ranking (Hypothesis 1). However, we anticipate that the ranking may not be universal, with a few countries deviating from the general pattern.

\section{Country-level Determinants of Welfare Deservingness}

Furthermore, we expect to find more substantial variation across countries in the solidarity index (a summary measurement of deservingness perceptions defined as the percentage of all groups seen as deserving by individuals), as well as the perceived deservingness of each of the five vulnerable groups. As pointed out before, differences across the transition countries are the most salient in relation to economic development, welfare spending and social outcomes. There is little literature concerning the effects of these variables on welfare deservingness per se, but valuable insights can be gained from studies that have analysed how these three factors influence various opinions concerning welfare, such as support for redistribution, preferences for public provision of welfare and perceived consequences of the welfare state.

\section{Level of economic development}


There are two opposing hypotheses regarding the potential link between the level of economic development and attitudes towards the welfare state. One argument is that a lower level of economic development is correlated with higher need, which in turn prompts stronger support for state intervention to remedy it. Another argument is that the general affluence of a country makes people less concerned about the costs of welfare provision, which they must fund through taxes, and people are thus more sympathetic to the groups in need.

The empirical results from existing studies do not provide decisive evidence in support of either argument, or about the importance of GDP per capita in shaping opinions about the welfare state. In an analysis covering a sample of 22 advanced welfare states, Finseraas (2009) found no correlation between GDP per capita and support for redistribution. Similar results were reported by Schmidt-Catran (2016) in a cross-sectional and longitudinal study covering 27 countries. However, exploring redistribution preferences in 50 developed and developing countries, Dion and Birchfield (2010) found that lower levels of economic development are associated with higher support for redistribution. Since our sample is more similar to Dion and Birchfield's in terms of the large variation in the levels of GDP (in relative terms), we expect that countries with higher GDP per capita will have lower levels of perceived deservingness regarding all groups (Hypothesis 2).

\section{Welfare spending}

Regarding the effects of welfare spending, the evidence is again mixed. In a crosssectional study covering 23 high-income countries, Dallinger (2010) found that support for redistribution increases in line with social protection spending. The same was reported by Jæger (2006), drawing on the results of a study of 13 European countries. However, in a later study using a pseudo-panel method, Jæger (2013) also found welfare spending to be unrelated to redistribution preferences. Likewise, analysing support for public healthcare, pensions and 
unemployment insurance in a sample of 15 OECD countries, Jordan (2013) found that total social protection spending was not related to preferences in any of these three policy areas. The evidence is somewhat more encouraging with studies exploring welfare attitudes other than the preference for income redistribution. In their study of perceptions of underuse and overuse of welfare benefits in 25 European countries, Roosma and colleagues (2016) found that lower social protection spending increases the perceptions that people receive less benefits than they are entitled to, but that higher expenditure does not increase the perceptions of welfare benefit abuse or fraud. In addition, van Oorschot and colleagues (2012) found that higher social protection spending is correlated with stronger perceptions of both positive and negative long-term effects of public welfare provision.

Despite the inconclusive evidence, we expect that the higher the aggregate social protection spending and specific programme-level expenditure is, the lower will be the solidarity index and individual group deservingness levels respectively (Hypothesis 3 ). The reason for this is that in the context of higher need, the implications of inadequate social protection spending (e.g., very low or non-existent expenditure on unemployment and/or family benefits observed in some transition countries) should intuitively be more salient.

\section{Social outcomes}

For social outcomes, the only variable for which recent data is available for all the countries in our sample is the unemployment rate. Previous studies have argued that a high prevalence of unemployment is correlated with higher perceived deservingness of unemployed people for two reasons. The first is that high unemployment raises the general fear of experiencing this risk, so people more easily sympathize with fellow citizens who have no job (Blekesaune and Quadagno, 2003; Bryson, 1997). The second is that during times of high unemployment, people are less likely to blame the unemployed for being idle, 
thus their public image is more favourable (Eardley and Matheson, 1999; Gallie and Paugam, 2002). Both cross-sectional and longitudinal studies provide support for this hypothesis. In a study of 24 countries, Blekesaune and Quadagno (2003) found that support for government assuming responsibility for the welfare of unemployed people, as well as providing everyone with a job, was higher in countries where larger proportions of people reported being unemployed. Using cross-sectional and longitudinal data, Fraile and Ferrer (2005) showed that in European countries with higher rates of unemployment, people are less supportive of cuts to unemployment benefits. In their analysis of Australian time-series data, Eardley and Matheson (1999) identified a strong negative correlation between the unemployment rate and internal attribution for unemployment. Similarly, Jeene and colleagues (2014) found that in the Netherlands, people were more concerned about the insufficiency of social assistance and unemployment benefits during periods of higher unemployment. Based on this evidence, we predict that in countries with higher unemployment rates, the perceived welfare deservingness of unemployed people will be higher (Hypothesis 4).

\section{Demography}

Transition countries also differ considerably in terms of demographics: while many are gradually converging with advanced welfare states in terms of fertility rates falling below the threshold required for population reproduction (2.1 births per woman) and ageing of the population, Central Asian countries and Azerbaijan have much higher fertility rates and lower life expectancy, resulting in smaller proportions of elderly people in the population. To take this into account, our models control for old and young-age dependency ratios and fertility rates. While there seems to be no empirical evidence for the effects of these characteristics on which to base our expectations, intuitively, we anticipate that the larger the proportion of these groups in the population, the lower their perceived deservingness levels, as this would 
require more resources. Hence, we expect that countries with higher ratios of old-age dependency will have lower levels of the perceived deservingness of elderly people (Hypothesis 5a). Similarly, countries with higher young-age dependency ratios and fertility rates will have lower levels of the perceived deservingness of families with children (Hypothesis 5b).

\section{Migration}

The transition period has been characterized by large-scale migration in post-communist nations (Black et al., 2012; Denisenko et al., 2020). The reasons for moving to another country have been manifold: some people have sought to return to their historic homelands (either within or outside the region), others have been displaced by armed conflicts and yet more have fled dire economic situations. Economic migration remains prevalent. As in the case of other social outcomes, there are large differences in the extent and type of migration between postcommunist countries. Some, for example Tajikistan and Uzbekistan, are major exporters of labour and rely disproportionately strongly on remittances. Others, such as Russia and Ukraine, attract large groups of migrants, while a significant proportion of their citizens also move abroad. Some migrants leave for good, whereas others move back and forth between countries seasonally. Some migrants, especially from post-communist, EU member countries, work abroad legally and enjoy the same rights as native citizens, whereas others, especially from Central Asian countries, often work illegally; a situation that restricts them to taking lowquality, low-paid and insecure jobs.

The differences in migration profiles may have substantial repercussions for the welfare deservingness of various vulnerable groups in transition countries. For example, the unemployed may be viewed as less deserving where going abroad to find work is a common practice, or in countries where there are a large number of foreign workers. Because people tend to hold generally less-favourable attitudes towards migrants (Reeskens and van der Meer, 2019) and migrants are usually poorer than the rest of the population, sympathy towards poor people may also be lower in countries with a large proportion of migrants. Hence, it is highly regrettable that a lack of reliable and comparable disaggregated data on migration hinders us from exploring its potential influence on welfare deservingness perceptions. 


\section{Individual-level Determinants}

Despite the importance of the country-level determinants, existing literature about welfare attitudes asserts that most of the variation in perceived welfare deservingness and other attitudes towards the welfare state occur at the individual level. The factors that influence people's welfare opinions reflect their self-interest and attitudinal dispositions towards concepts such as equality, social rights, the causes of poverty and the role of state, market and family (Blekesaune and Quadagno, 2003; Groskind, 1994; Hasenfeld and Rafferty, 1989). With regard to self-interest, multiple studies have shown that people with lower socioeconomic status (such as those on a low income, or with lower educational status and in insecure employment) - resulting in higher exposure to various social risks - are more in favour of government provision and redistribution (Andress and Heien, 2001; Blekesaune and Quadagno, 2003; Edlund, 1999; Jordan, 2013; Svallfors, 1997). We expect to find the same in relation to the solidarity index, as well the perceived deservingness of each of the five groups (Hypothesis 6a). However, there is one important caveat. There is some evidence that people in certain vulnerable groups may view other groups as competitors for scarce public resources, and accordingly consider them as less deserving. For example, testing the existence of intergenerational conflict over welfare resources, Busemeyer and colleagues (2009) found elderly people to be considerably less supportive of spending on education and more supportive of pension spending compared with younger people. Similarly, Gugushvili (2018) found that in the South Caucasian countries, poor people were more opposed to extending social assistance schemes than other people, allegedly since this might negatively affect their financial situation. Thus we anticipate that people belonging to one of the five vulnerable groups will have lower odds of viewing the other vulnerable groups as deserving (Hypothesis 6b). 
The evidence regarding the effects of ideational predictors consistently shows that people who are more left-wing, egalitarian, sympathetic towards poor people and sceptical of the market economy are more supportive of income redistribution and welfare provision (Blekesaune and Quadagno, 2003; Groskind, 1994; Sihvo and Uusitalo, 1995). The same is observed in transition countries in general (Gugushvili, 2018; Habibov, 2013; van Oorschot and Gugushvili, 2019), with the exception of left-right political orientation, but this is likely due to the fact that in formerly communist countries people perceive this continuum in a way that differs from that in mature democracies (Tavits and Letki, 2009). Therefore, we expect that more-egalitarian people will perceive each of the five vulnerable groups as more deserving (Hypothesis 7).

Lastly, we control for gender, age, religion and urban-rural residence. The latter is important, as unlike the affluent industrialized nations, in many transition countries a large proportion of the population live in rural areas and engage in small-scale farming, which contributes to them having a considerably higher risk of poverty. This may also influence perceptions of welfare deservingness: for example, Gugushvili (2018) found that in the South Caucasus, people living in rural areas and small cities were more opposed to the extension of social assistance than residents of the capital cities.

\section{Methodology}

\section{Data Source}

The LiT survey is commissioned by the European Bank for Reconstruction and Development (EBRD) to collect information about the effects of the transition on the lives of people in post-communist countries and their views about various political, economic and social issues. The third round was fielded in 34 countries in 2016, including five non-transition countries 
for comparison purposes. ${ }^{3}$ We use data from 25 transition countries, excluding Bosnia and Herzegovina, Kosovo, Macedonia and Montenegro due to the absence of data on some key macro-level variables. In each country, a nationally representative sample of 1,500 households were interviewed.

\section{Dependent Variables}

The dependent variables are derived through a question that presents a list of vulnerable groups and asks for each one whether they deserve support from the government. The solidarity index is the percentage of all five groups the respondent considers deserving.

\section{Individual-level Predictors}

The self-interest variables used in the analysis include employment status, education level and household income. The employment categories are: employed, unemployed, retired, disabled, and others. Education levels are lower secondary or below, upper secondary and vocational, and higher. Income is assessed by subjective placement on a ten-step ladder.

We also use seven ideational variables. Preference for redistribution is derived through a question that asks to what extent the respondent agrees with the statement that the gap between the rich and the poor should be reduced in the country $(1=$ "strongly disagree" to 5 = "strongly agree"). Sympathy towards poor people is based on a question that asks

\footnotetext{
${ }^{3}$ The non-transition countries that participated in the LiT 2016 were Cyprus, Germany, Greece, Italy and Turkey. Because this group is dominated by Mediterranean countries and does not include any Scandinavian or Anglo-Saxon ones, we did not use them for comparisons between transition and non-transition countries.
} 
whether the respondent would be willing to give part of their own income or pay more taxes if they were sure that the extra money would be used to help the needy. Attitude towards market economy is dichotomous, indicating whether or not the respondent thinks that a market economy is preferable to any other form of economic system. Attribution of poverty divides respondents into two categories: those who think that the main reason some people in the country are poor is injustice in society, and those who think that it is due to poor people being unlucky, lazy or lacking willpower, or poverty being an inevitable part of modern life. Attitude towards meritocracy is measured on a ten-point scale, with 1 being "Incomes should be made more equal" and 10 being "We need larger income differences as incentives for individual effort". Attitude towards ownership of business and industry is also measured on a ten-point scale, with 1 implying maximum support for private ownership and 10 for public ownership. Similarly, attitude towards competition ranges from 1, "Competition is good. It stimulates people to work hard and develop new ideas" to 10 , "Competition is harmful. It brings out the worst in people".

\section{Control Variables}

To take into account the possible non-linear relationships between age and the dependent variables, respondents' age is separated into four quartiles: $18-34,35-48,49-62$ and aged 62 or older. Health status is based on a subjective evaluation ranging from "very good" to "very bad". Religion categories are: Christian, Muslim, other and non-religious. We also control for gender and urban/rural residency.

\section{Country-level Predictors}

In the analysis we use economic, social spending, unemployment and demographic variables. 
The level of economic development is measured by GDP per capita in PPP terms (constant 2011 international \$) in 2016. Social protection spending is measured as the proportion of GDP. We use both the aggregate social protection spending (including public healthcare) and expenditure on functions corresponding to our groups of interest: old-age people; unemployment benefits and labour market programmes; sickness, maternity, employment, injury and disability; children; and general social assistance. Unemployment rate is based on modelled ILO estimates. Young-age dependency ratio is the ratio of people younger than 15 to the working-age population of 15-64 years old. Similarly, old-age dependency ratio is the ratio of people older than 64 to the working population aged 15-64. Fertility rate is measured as the average number of births per woman. All variables except the social spending ones were obtained from the World Bank's Open Data source. Social expenditure figures come from ILO’s (2017) report.

\section{Analytical Strategy}

In the first stage of the analysis we inspected the descriptive statistics for the pooled sample, geographic regions and individual countries. Next we fitted multi-level logistic regression models for the dependent variables measuring the deservingness of each of the five groups in need, and multilevel ordinary least squares regression models for the solidarity index, as unlike the other dependent variables it is a continuous one.

\section{Results}

We start with a descriptive analysis by inspecting the rank order of welfare deservingness across the pooled sample. As Figure 1 shows, the overall hierarchy is similar to that observed for Western welfare states in previous research: the highest support is expressed for disabled people ( 72 per cent), followed by the elderly (67 per cent) and families with children (63 per cent). As expected, unemployed people and the working poor are viewed as considerably less 
deserving (46 and 47 per cent respectively). Hence, our first hypothesis is supported by the data.

Figure 1. Welfare deservingness of five vulnerable groups, pooled sample

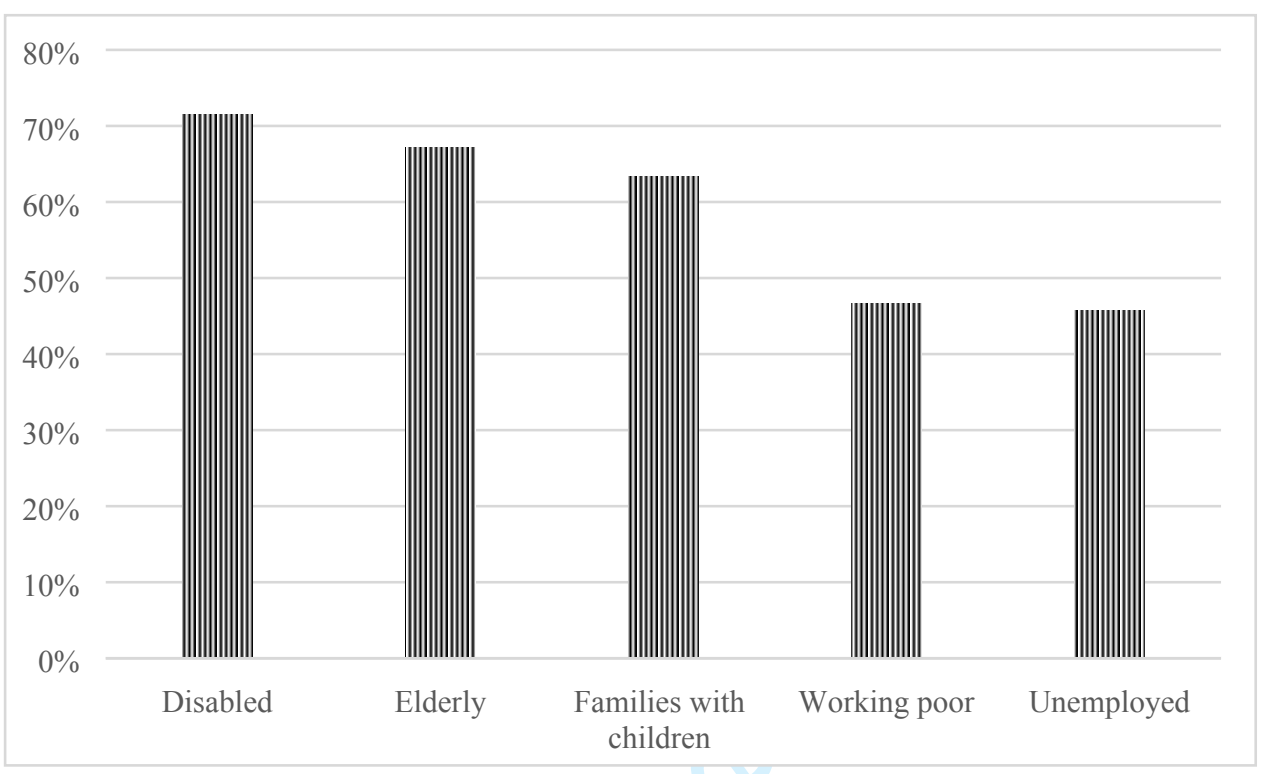

Source: LiT (2016).

The descriptive analysis also reveals a large variation in the levels of perceived deservingness across countries for both the solidarity index and the individual group deservingness levels. In Azerbaijan, only 41 per cent of people consider elderly people to be deserving of welfare, compared with 98 per cent in Georgia (Table 1). Disabled people are considered deserving by only 44 per cent of Hungarians, but by more than 95 per cent of Belarusians, Georgians, Kazakhs, Belarusians and Ukrainians. Only one in five Albanians (21 per cent) think that the government should provide support for families with children, while in Kazakhstan this proportion is 92 per cent. The working poor receive the least sympathy in Uzbekistan (18 per cent) and Russia (22 per cent), and the most in Georgia (87 per cent) and Kazakhstan (78 per cent). Together with Lithuanians and Czechs, Russians are also the least supportive of unemployed people, with Georgians ( 88 per cent) and Ukrainians (71 per cent) being at the other extreme. Given such large differences, it comes as no surprise 
that the solidarity index also varies a great deal, with the lowest levels observed in Azerbaijan and Uzbekistan and the highest in Georgia and Kazakhstan. Georgia is a clear outlier, with anomalously high levels of support for all groups, which might benefit from further research.

Table 1. Average levels of perceived deservingness in transition countries

\begin{tabular}{|c|c|c|c|c|c|c|}
\hline & Disabled & Elderly & $\begin{array}{l}\text { Fam. w/ } \\
\text { Children }\end{array}$ & $\begin{array}{c}\text { Working } \\
\text { Poor }\end{array}$ & Unempl. & $\begin{array}{l}\text { Solidarity } \\
\text { Index }\end{array}$ \\
\hline Georgia & $\begin{array}{c}0.989 \\
(0.003)\end{array}$ & $\begin{array}{c}0.979 \\
(0.005)\end{array}$ & $\begin{array}{c}0.956 \\
(0.007)\end{array}$ & $\begin{array}{c}0.871 \\
(0.012)\end{array}$ & $\begin{array}{c}0.884 \\
(0.012)\end{array}$ & $\begin{array}{c}0.936 \\
(0.003)\end{array}$ \\
\hline Kazakhstan & $\begin{array}{c}0.958 \\
(0.006)\end{array}$ & $\begin{array}{c}0.942 \\
(0.007)\end{array}$ & $\begin{array}{c}0.917 \\
(0.008)\end{array}$ & $\begin{array}{c}0.782 \\
(0.013)\end{array}$ & $\begin{array}{c}0.69 \\
(0.015)\end{array}$ & $\begin{array}{c}0.858 \\
(0.004)\end{array}$ \\
\hline Ukraine & $\begin{array}{c}0.952 \\
(0.007)\end{array}$ & $\begin{array}{c}0.945 \\
(0.007)\end{array}$ & $\begin{array}{c}0.88 \\
(0.014)\end{array}$ & $\begin{array}{c}0.698 \\
(0.017)\end{array}$ & $\begin{array}{c}0.71 \\
(0.016)\end{array}$ & $\begin{array}{c}0.837 \\
(0.004)\end{array}$ \\
\hline Kyrgyz Rep. & $\begin{array}{c}0.916 \\
(0.009)\end{array}$ & $\begin{array}{c}0.884 \\
(0.011)\end{array}$ & $\begin{array}{c}0.858 \\
(0.011)\end{array}$ & $\begin{array}{c}0.688 \\
(0.015)\end{array}$ & $\begin{array}{c}0.671 \\
(0.015)\end{array}$ & $\begin{array}{c}0.803 \\
(0.005)\end{array}$ \\
\hline Belarus & $\begin{array}{c}0.958 \\
(0.005)\end{array}$ & $\begin{array}{l}0.902 \\
(0.01)\end{array}$ & $\begin{array}{c}0.84 \\
(0.011)\end{array}$ & $\begin{array}{c}0.556 \\
(0.015)\end{array}$ & $\begin{array}{c}0.547 \\
(0.015)\end{array}$ & $\begin{array}{c}0.761 \\
(0.002)\end{array}$ \\
\hline Tajikistan & $\begin{array}{c}0.829 \\
(0.012)\end{array}$ & $\begin{array}{c}0.701 \\
(0.015)\end{array}$ & $\begin{array}{c}0.566 \\
(0.015)\end{array}$ & $\begin{array}{c}0.623 \\
(0.015)\end{array}$ & $\begin{array}{c}0.628 \\
(0.015)\end{array}$ & $\begin{array}{c}0.669 \\
(0.002)\end{array}$ \\
\hline Moldova & $\begin{array}{c}0.801 \\
(0.014)\end{array}$ & $\begin{array}{c}0.853 \\
(0.013)\end{array}$ & $\begin{array}{c}0.718 \\
(0.016)\end{array}$ & $\begin{array}{c}0.478 \\
(0.017)\end{array}$ & $\begin{array}{c}0.413 \\
(0.016)\end{array}$ & $\begin{array}{c}0.653 \\
(0.003)\end{array}$ \\
\hline Armenia & $\begin{array}{c}0.798 \\
(0.015)\end{array}$ & $\begin{array}{c}0.683 \\
(0.017)\end{array}$ & $\begin{array}{c}0.621 \\
(0.017)\end{array}$ & $\begin{array}{c}0.51 \\
(0.018)\end{array}$ & $\begin{array}{c}0.516 \\
(0.018)\end{array}$ & $\begin{array}{c}0.626 \\
(0.003)\end{array}$ \\
\hline Poland & $\begin{array}{c}0.726 \\
(0.023)\end{array}$ & $\begin{array}{c}0.758 \\
(0.022)\end{array}$ & $\begin{array}{c}0.642 \\
(0.026)\end{array}$ & $\begin{array}{c}0.508 \\
(0.027)\end{array}$ & $\begin{array}{c}0.493 \\
(0.027)\end{array}$ & $\begin{array}{c}0.625 \\
(0.004)\end{array}$ \\
\hline Slovenia & $\begin{array}{c}0.586 \\
(0.015)\end{array}$ & $\begin{array}{c}0.519 \\
(0.015)\end{array}$ & $\begin{array}{c}0.633 \\
(0.015)\end{array}$ & $\begin{array}{c}0.675 \\
(0.014)\end{array}$ & $\begin{array}{c}0.422 \\
(0.015)\end{array}$ & $\begin{array}{c}0.567 \\
(0.003)\end{array}$ \\
\hline Estonia & $\begin{array}{c}0.704 \\
(0.014)\end{array}$ & $\begin{array}{c}0.585 \\
(0.015)\end{array}$ & $\begin{array}{c}0.782 \\
(0.013)\end{array}$ & $\begin{array}{c}0.382 \\
(0.015)\end{array}$ & $\begin{array}{c}0.341 \\
(0.015)\end{array}$ & $\begin{array}{c}0.559 \\
(0.002)\end{array}$ \\
\hline Croatia & $\begin{array}{c}0.601 \\
(0.014)\end{array}$ & $\begin{array}{c}0.604 \\
(0.014)\end{array}$ & $\begin{array}{c}0.509 \\
(0.014)\end{array}$ & $\begin{array}{c}0.423 \\
(0.014)\end{array}$ & $\begin{array}{c}0.639 \\
(0.013)\end{array}$ & $\begin{array}{c}0.555 \\
(0.002)\end{array}$ \\
\hline Czech Rep. & $\begin{array}{c}0.73 \\
(0.013)\end{array}$ & $\begin{array}{c}0.676 \\
(0.014)\end{array}$ & $\begin{array}{c}0.719 \\
(0.013)\end{array}$ & $\begin{array}{c}0.415 \\
(0.015)\end{array}$ & $\begin{array}{c}0.193 \\
(0.012)\end{array}$ & $\begin{array}{c}0.547 \\
(0.002)\end{array}$ \\
\hline Latvia & $\begin{array}{c}0.707 \\
(0.014)\end{array}$ & $\begin{array}{c}0.69 \\
(0.014)\end{array}$ & $\begin{array}{c}0.772 \\
(0.012)\end{array}$ & $\begin{array}{c}0.327 \\
(0.014)\end{array}$ & $\begin{array}{c}0.222 \\
(0.012)\end{array}$ & $\begin{array}{c}0.544 \\
(0.002)\end{array}$ \\
\hline Serbia & $\begin{array}{c}0.576 \\
(0.014)\end{array}$ & $\begin{array}{c}0.539 \\
(0.014)\end{array}$ & $\begin{array}{c}0.554 \\
(0.014)\end{array}$ & $\begin{array}{c}0.464 \\
(0.014)\end{array}$ & $\begin{array}{c}0.562 \\
(0.014)\end{array}$ & $\begin{array}{c}0.539 \\
(0.002)\end{array}$ \\
\hline Bulgaria & $\begin{array}{c}0.689 \\
(0.014)\end{array}$ & $\begin{array}{c}0.668 \\
(0.014)\end{array}$ & $\begin{array}{c}0.558 \\
(0.015)\end{array}$ & $\begin{array}{c}0.309 \\
(0.014)\end{array}$ & $\begin{array}{c}0.431 \\
(0.015)\end{array}$ & $\begin{array}{c}0.531 \\
(0.002)\end{array}$ \\
\hline
\end{tabular}




\begin{tabular}{lcccccc} 
Slovak Rep. & 0.517 & 0.614 & 0.731 & 0.451 & 0.307 & 0.524 \\
Lithuania & $(0.016)$ & $(0.016)$ & $(0.014)$ & $(0.016)$ & $(0.015)$ & $(0.003)$ \\
& 0.662 & 0.624 & 0.688 & 0.424 & 0.183 & 0.516 \\
Romania & $(0.014)$ & $(0.014)$ & $(0.014)$ & $(0.015)$ & $(0.012)$ & $(0.002)$ \\
& 0.617 & 0.68 & 0.522 & 0.396 & 0.311 & 0.505 \\
Mongolia & $(0.015)$ & $(0.014)$ & $(0.015)$ & $(0.015)$ & $(0.015)$ & $(0.003)$ \\
& 0.689 & 0.527 & 0.398 & 0.32 & 0.357 & 0.458 \\
Albania & $(0.014)$ & $(0.015)$ & $(0.015)$ & $(0.014)$ & $(0.015)$ & $(0.002)$ \\
& 0.549 & 0.522 & 0.207 & 0.328 & 0.64 & 0.449 \\
Russia & $(0.015)$ & $(0.015)$ & $(0.012)$ & $(0.014)$ & $(0.014)$ & $(0.002)$ \\
& 0.67 & 0.596 & & 0.222 & 0.184 & 0.444 \\
Hungary & $(0.017)$ & $(0.019)$ & $0.55(0.02)$ & $(0.017)$ & $(0.018)$ & $(0.004)$ \\
& 0.439 & 0.433 & 0.596 & 0.413 & 0.324 & 0.441 \\
Uzbekistan & $(0.015)$ & $(0.015)$ & $(0.015)$ & $(0.015)$ & $(0.015)$ & $(0.003)$ \\
& 0.696 & 0.453 & 0.34 & 0.181 & 0.362 & 0.407 \\
Azerbaijan & $(0.014)$ & $(0.015)$ & $(0.014)$ & $(0.011)$ & $(0.015)$ & $(0.002)$ \\
& 0.525 & 0.411 & 0.276 & 0.228 & 0.421 & 0.372 \\
Source: LiT & $(0.018)$ & $(0.018)$ & $(0.017)$ & $(0.017)$ & $(0.018)$ & $(0.005)$ \\
\hline
\end{tabular}

Source: LiT (2016). Note: Standard errors in parentheses.

Differences across geographical regions are less pronounced, but nonetheless substantial (Figure 2). The Balkan region is characterized by low deservingness levels for all groups except the unemployed. Support for elderly and disabled people is the lowest in Central European countries. The Baltic region is distinguished by the highest level of perceived deservingness of families with children and the lowest support for unemployed people. Caucasians are the most sympathetic towards the new groups of vulnerable people while the old groups receive the strongest support in the western part of the former USSR. Similar to the Caucasus, each vulnerable group is considered as deserving by more than half of people in Central Asia.

Figure 2. Average levels of welfare deservingness by geographic regions 

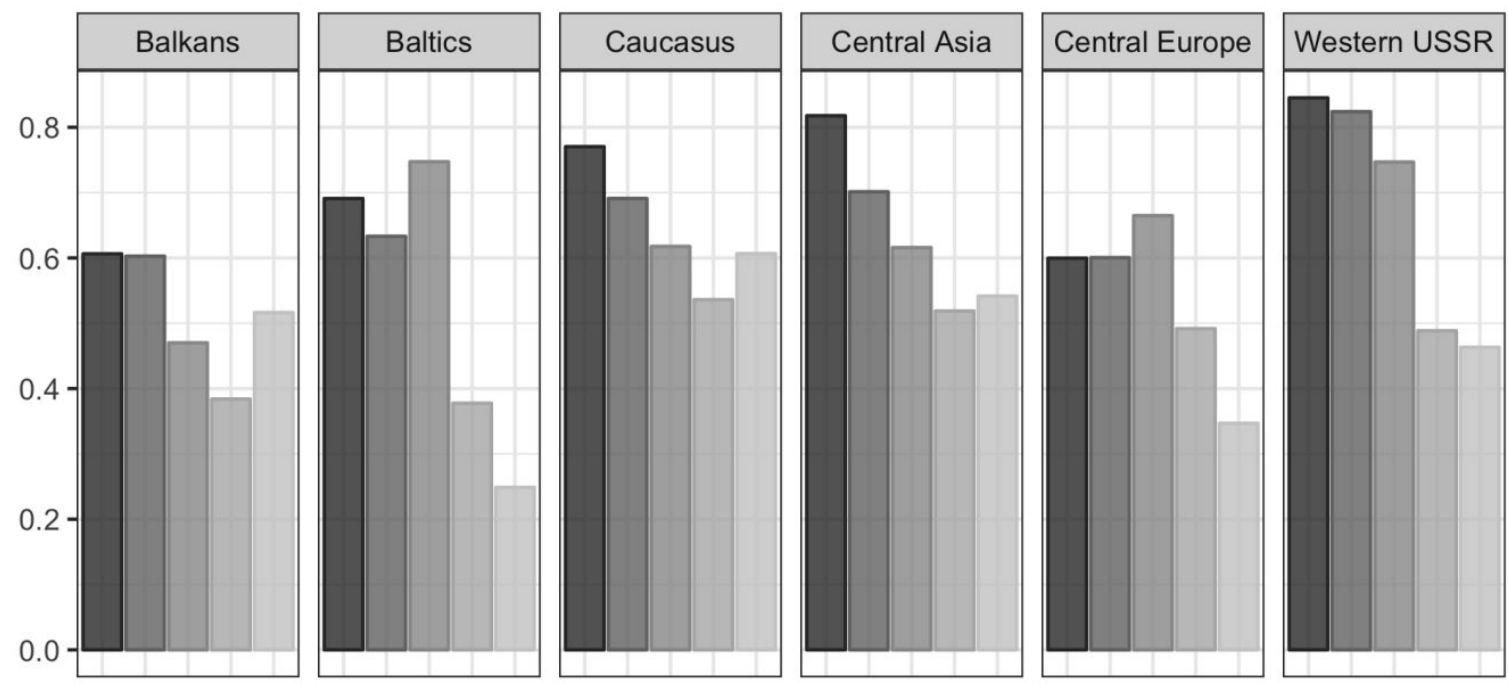

Disabled

Elderly Families WorkingPoor Unemployed

Source: LiT (2016). Note: the Balkan region includes Albania, Bulgaria, Croatia, Serbia, Slovenia and Romania. The Baltic region comprises of Estonia, Latvia and Lithuania. The Caucasus region includes Armenia, Azerbaijan and Georgia. The Central Asian countries are Kazakhstan, Kyrgyzstan, Mongolia, Tajikistan and Uzbekistan. The Central Europe region comprises of the Czech Republic, Hungary, Poland and Slovakia. The western part of former USSR includes Belarus, Moldova, Russia and Ukraine.

The large differences across countries suggest that specific characteristics of these countries have a substantial influence over people's deservingness perceptions. This is confirmed by multilevel null-models, which yield intra-class correlation coefficients substantially exceeding the conventional 5 per cent threshold beyond which multilevel modelling is deemed appropriate (Table 2). ${ }^{4}$

\footnotetext{
${ }^{4}$ Since the dependent variables for solidarity are categorical, the individual error terms e $i j$ are assumed to follow standard logistic distribution and hence the intra-class correlation for multilevel logistic regression is calculated as ICC $=\frac{\text { country-level variance }}{\left(\text { country-level variance }+\pi^{\frac{2}{3}}\right)}$. For more information see Rodríguez and Elo (2003).
} 
Table 2. Intra-class correlations of dependent variables

\begin{tabular}{|l|l|}
\hline Variable & ICC \\
\hline Solidarity index & 0.247 \\
\hline Elderly & 0.265 \\
\hline Disabled & 0.299 \\
\hline Families with children & 0.244 \\
\hline Working poor & 0.157 \\
\hline Unemployed & 0.175 \\
\hline
\end{tabular}

Source: LiT (2016).

To tap into the causes of these variations, we fitted multilevel logistic models (and multilevel regression models for the solidarity index) with individual controls, adding the available macro-level variables one at a time. In line with Hypothesis 2, we found that higher levels of economic development are associated with lower levels of perceived deservingness of elderly, unemployed and disabled people (Figure 3). However, GDP per capita is not related to the perceived deservingness of families with children or the working poor, or to the solidarity index.

Figure 3. Effects of GDP per capita on welfare deservingness

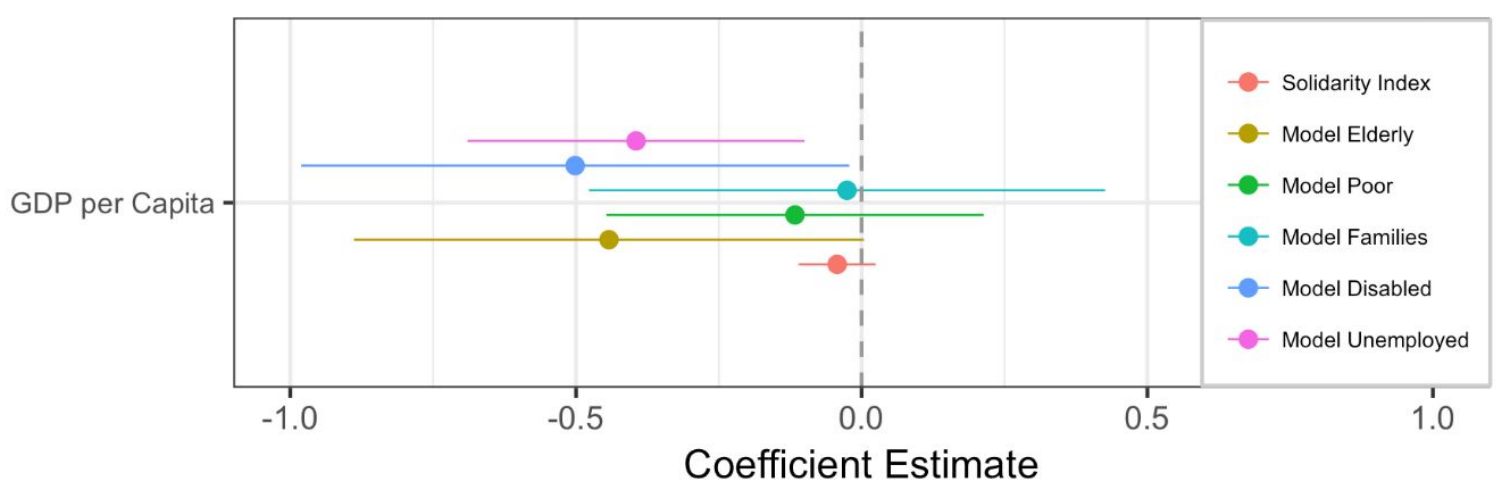

Sources: LiT (2016), World Bank (2020). Note: the models control for individual-level predictors.

In contrast to economic development, social spending appears to be completely uncorrelated with perceived welfare deservingness. We found no statistically significant association between total spending and the solidarity index, or between group-specific 
spending and the deservingness of individual groups (Figure 4). Thus, the data does not support our third hypothesis.

Figure 4. Effects of social spending on welfare deservingness

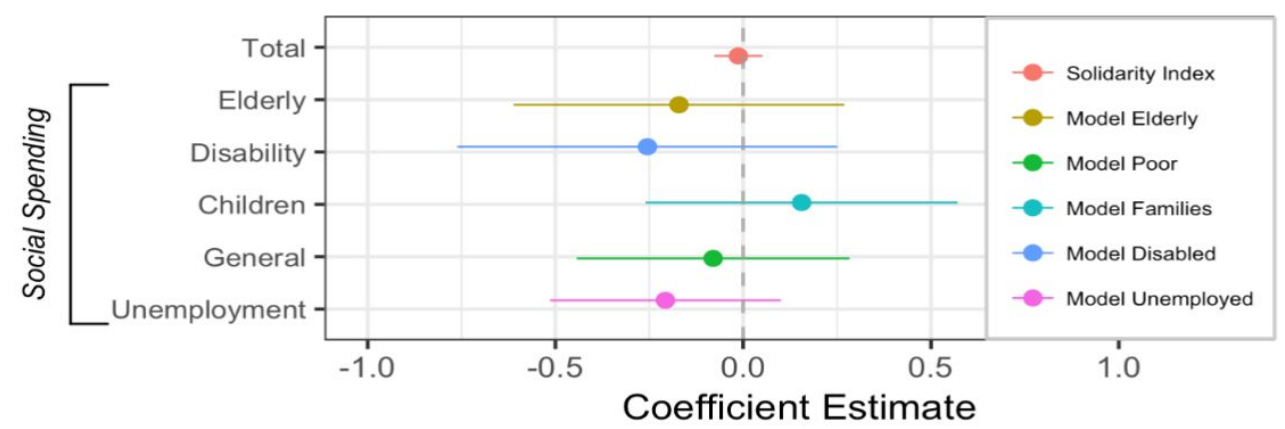

Sources: LiT (2016), ILO (2017). Note: the models control for individual-level predictors.

Counterintuitively, the rate of unemployment also does not appear to influence the perceived deservingness of unemployed people (Figure 5). One possible reason is that the unemployment rate measured in line with the ILO standard (which considers anyone carrying out at least an hour of paid or unpaid work during the preceding week to be employed) is not very accurate to describe the labour market situation in poorer transition countries where large shares of the labour force are engaged in subsistence farming, thus counting as employed. Another potential explanation is that in some countries, low unemployment figures may simply reflect the fact that many citizens who could not find work have moved abroad. Whatever the reason, the fourth hypothesis is also not supported by the data.

Also surprisingly, demographic factors do not seem to influence the deservingness perceptions. We found no statistically significant correlation between the old-age dependency ratio and the deservingness of elderly people, or between the young-age dependency or fertility rates and the deservingness of the families with children (Figure 5). Hence, Hypothesis $5 \mathrm{a}$ and Hypothesis $5 \mathrm{~b}$ also are not supported by the data. 
Figure 5. Effects of unemployment rate and demographic variables on welfare deservingness

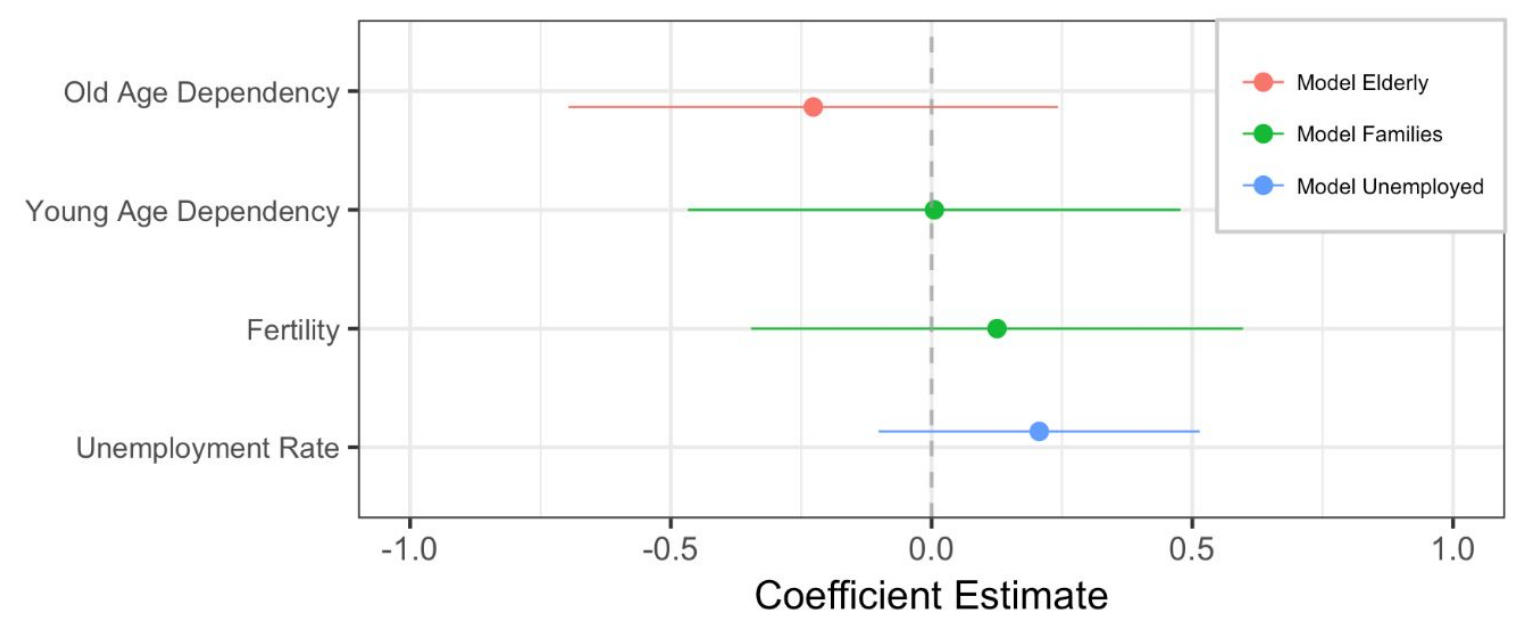

Sources: LiT (2016), World Bank (2020). Note: the models control for individual-level predictors.

Turning to individual-level predictors, the results are mainly in line with our expectations regarding both self-interest and ideational variables. Starting with the solidarity index, retired, disabled and unemployed people express higher solidarity than the employed and the non-disabled (Figure 6). Similarly, people who want the gap between the rich and the poor to be reduced and prefer more government ownership are more solidaristic, while internal attribution for poverty, a preference for meritocracy and a lack of desire to share resources with the poor all reduce solidarity. The only counterintuitive result is that people with favourable views about the market economy and competition are more solidaristic than others. Since these preferences are more in line with right-wing and non-egalitarian worldviews, we would expect that people holding them should be less solidaristic than others. Nevertheless, the results overall support our Hypothesis 6a and Hypothesis 7.

Figure 6. Effects of individual-level predictors on solidarity index 


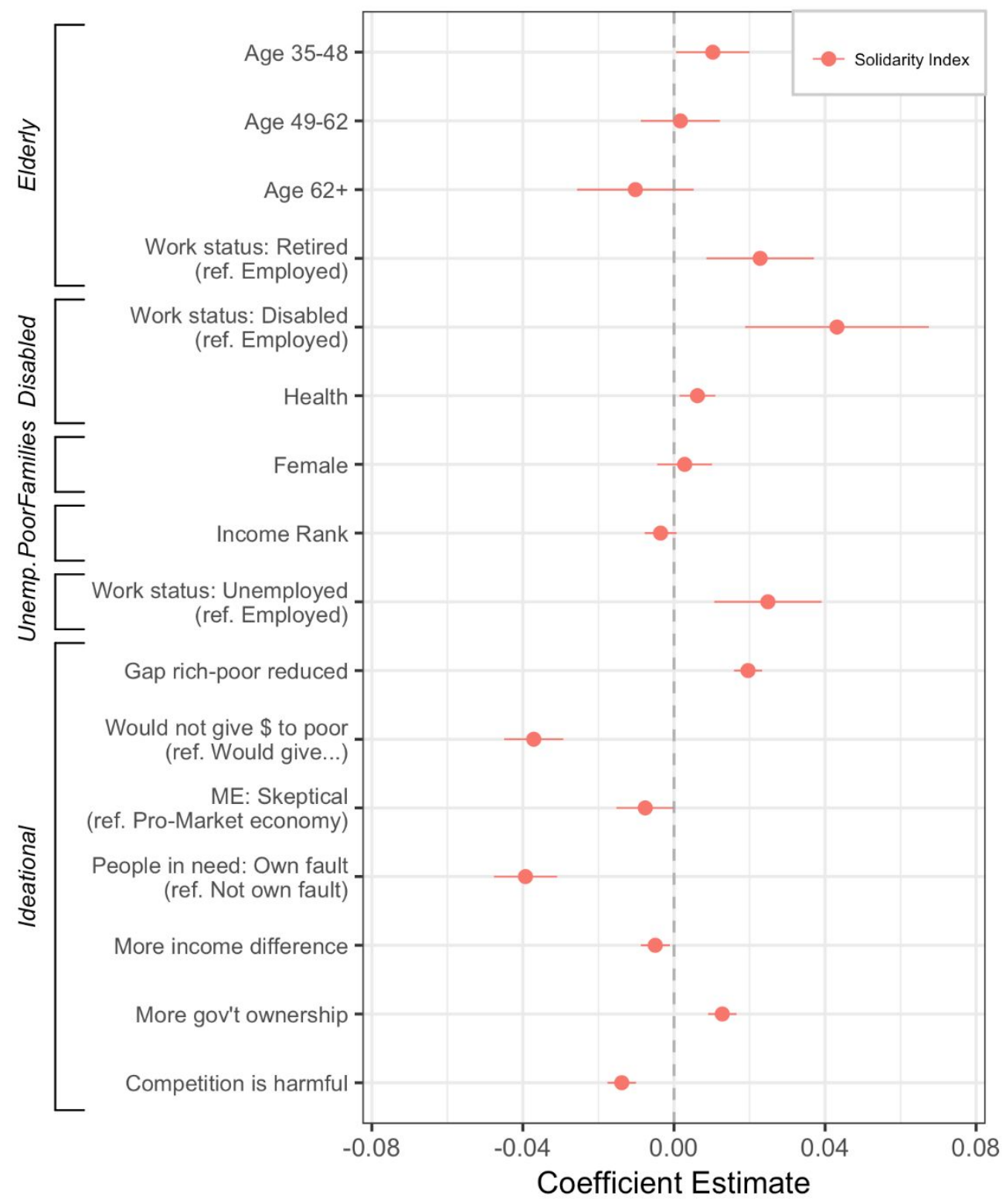

Source: LiT (2016).

Notes: Here and in the subsequent figures, the plotted points show the estimated coefficients (the effects) of the independent variables (on the left) on the dependent variable (attitudes towards families, the elderly, poor, disabled and unemployed, and the solidarity index — shown in the legend). As the models for attitudes are logistic regressions and independent variables are standardized (centred and divided by their respective standard deviations), these coefficients reflect a one standard deviation change in the independent variable being associated with a change of $X$ in the log odds of selecting the respective category as deserving. In the case of the solidarity index, the coefficient is interpreted as a one standard deviation change in the independent variable being associated with a change of $X$ in the solidarity index (range $0-1$ ). 
Further evidence regarding the importance of self-interest can be seen in Figure 7.

Disabled, elderly and unemployed people have the highest likelihood of viewing themselves as the most deserving. Similarly, women have a greater likelihood than men of viewing families with children as deserving. Lower income is also associated with higher chances of considering unemployed people and the working poor as deserving.

Figure 7. Effects of self-interest predictors on the deservingness of vulnerable groups

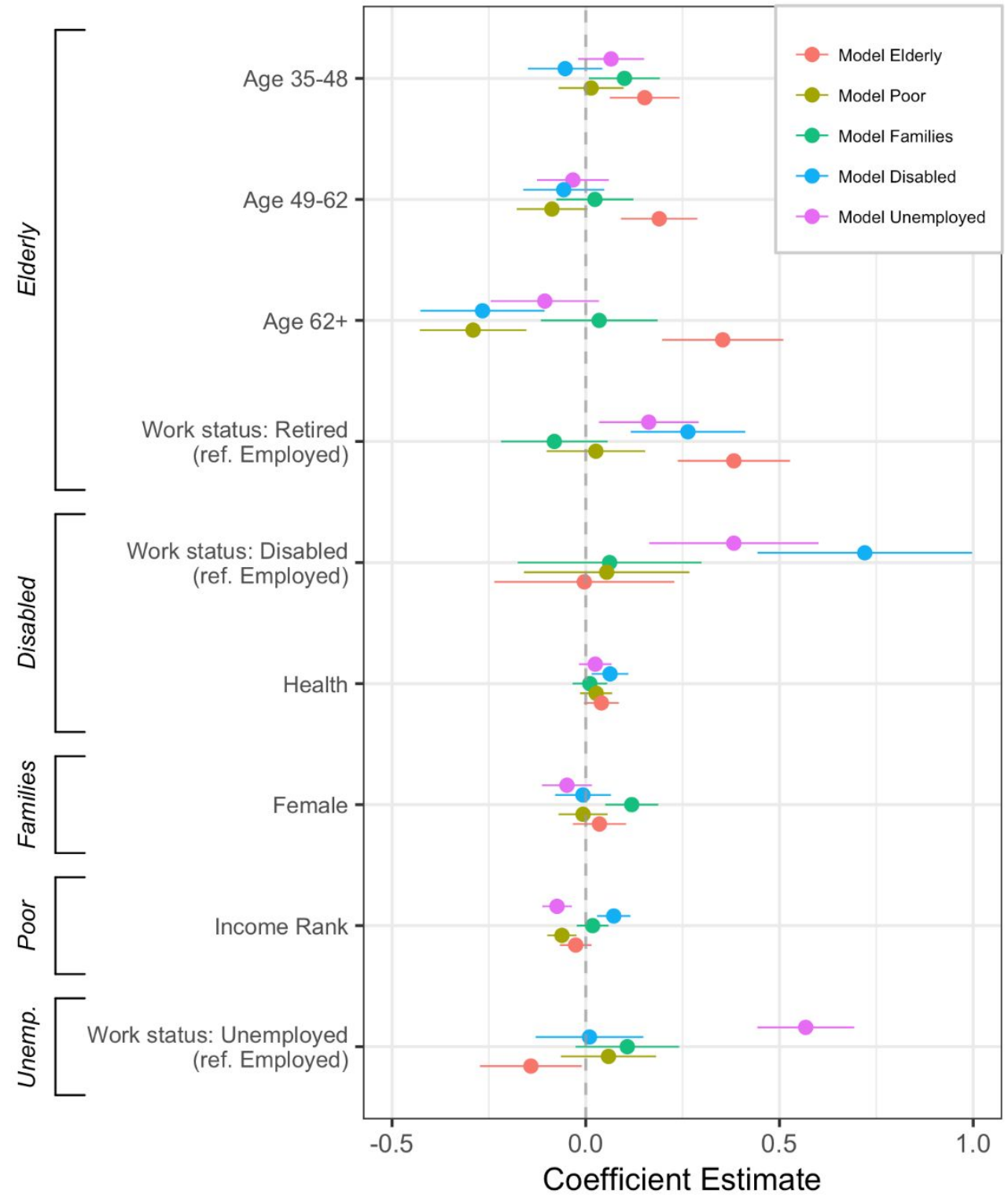

Source: LiT (2016). 
The correlation between ideational predictors and the deservingness of individual groups also confirms our expectations. People who want to see inequalities in income reduced and who favour more government ownership are more likely to consider any of the five groups as deserving, while the opposite is true in the case of people who oppose giving more money to the poor (Figure 8). Internal attribution for poverty also reduces the likelihood of viewing any of the groups, except disabled people, as deserving of welfare. A higher preference for meritocracy reduces the likelihood of being sympathetic towards unemployed people and the working poor. As in the case of the solidarity index, distrust of the market economy and competition counterintuitively reduce the likelihood of supporting the vulnerable groups.

Figure 8. Effects of ideational predictors on the deservingness of vulnerable groups

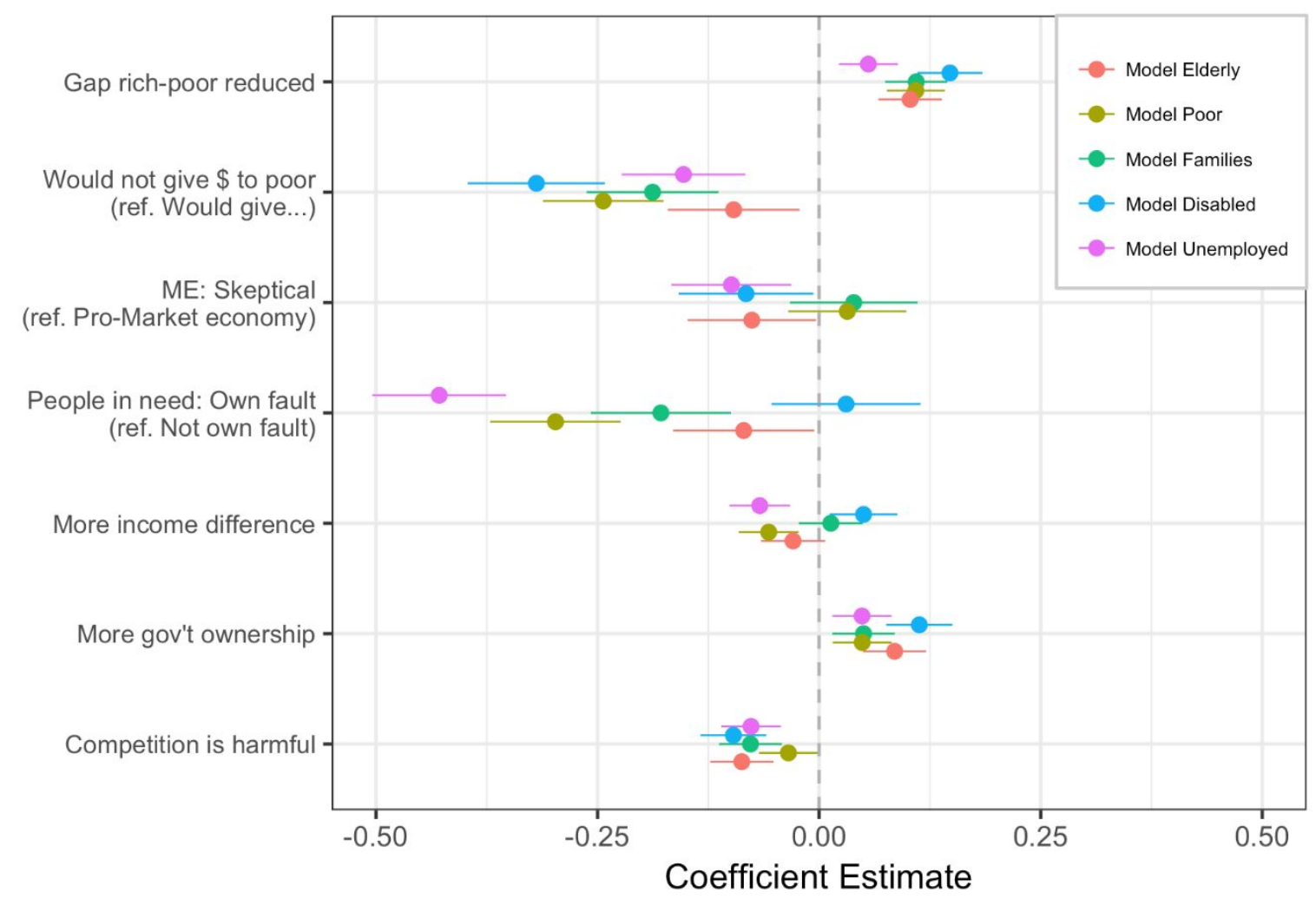

Source: LiT (2016). 
The results also provide some evidence in support of Hypothesis $6 \mathrm{~b}$, suggesting that vulnerable groups view other vulnerable groups as less deserving, presumably due to perceived competition for public resources. Illustrative of this are the cases where a vulnerable group has higher odds of viewing itself as deserving than the reference group, and lower probabilities of viewing other vulnerable groups as deserving. Figure 7 shows that among all the age groups, people aged 62 and above are the most likely to consider elderly people as worthy of public support and the least likely to identify disabled people and the working poor as deserving. Unemployed people on the other hand, are the most likely to consider themselves as deserving while having lower odds of viewing elderly people as deserving. This suggests that elderly people consider the working poor and disabled people as potential competitors, while for the unemployed, the perceived competitors are elderly people.

\section{Discussion and Conclusion}

This paper sought to shed light on the present state of people's solidarity with old and new groups of vulnerable people in post-communist countries, and the factors that influence these perceptions. Our results reveal that citizens in transition countries express more support for disabled and elderly people and families with children than for unemployed people and the working poor. However, this does not necessarily reflect the communist legacy of denying the existence of unemployment and poverty, or considering these people as idle, as similar differences are systematically found in Western welfare states. Instead, this suggests that people in both contexts apply similar criteria in a similar way to determine specific groups' deservingness.

Another key finding is that both the solidarity index and the perceived deservingness of each of the five vulnerable groups vary substantially across geographical regions, and 
much more so across countries. Our overarching hypothesis was that the causes of variation should be related to the major differences in economic performance and welfare provision that these countries had experienced since the start of the transition. However, our results only partially support this hypothesis: higher levels of economic development are indeed associated with a lower perceived deservingness of elderly, disabled and unemployed people - but the effects of welfare spending and unemployment rate are insignificant. This finding should be taken with a pinch of salt. The expenditure figures from different countries may not be fully compatible. In addition, the unemployment rate may not be an accurate measurement of the labour market conditions in some transition countries where sizeable proportions of the population are engaged in subsistence farming and where large-scale outward migration conceals the true extent of job scarcity. Moreover, the small size of the upper-level units (countries), a typical problem for comparative welfare research, is also likely to contribute to the insignificance of results. The only thing we can be certain of at this stage is that in transition countries, differences in perceived welfare deservingness are influenced by different levels of economic development. Future studies should consider alternative ways of testing the influence of welfare provision, for example by pooling data from several waves of the LiT to increase the country N-size. Provided that relevant data becomes available in the future, new research could also use alternative indicators of welfare provision, such as coverage, replacement rates and poverty incidence. New research would also benefit from extending the theoretical framework by considering the potential effects of cultural variables, such as work ethic, religiosity and religious denominations, conservatism/liberalism and collectivism/individualism.

Our results are more informative with regard to the roles of socioeconomic and ideological factors in shaping welfare preferences. With a few minor exceptions, our results are fully in line with the general findings of other research into welfare attitudes, suggesting 
that the theories of self-interest and ideological determinants of welfare deservingness are applicable well beyond the advanced Western welfare states. Lastly, our findings provide substantial evidence for the existence of welfare competition between some of the vulnerable groups, which could also be an interesting avenue for research in Western welfare states.

Our results also have practical implications that welfare policymakers in transition countries may wish to take into account, as they are faced with the permanent question of who should get what, and why. While the traditional welfare clientele still attract more sympathy from the public in most countries, in some, people are also concerned about the newly vulnerable groups, and over time this will probably require adequate reflection in public policies. The same is also true in relation to support for families with children, especially in Baltic and Central European countries where people in this group are viewed as more deserving than the elderly and the disabled.

\section{Bibliography}

Andress H-J and Heien T (2001) Four Worlds of Welfare State Attitudes? A Comparison of Germany, Norway, and the United States. European Sociological Review 17(4): 337356.

Atkinson AB and Micklewright J (1992) Economic Transformation in Eastern Europe and the Distribution of Income. Cambridge: Cambridge University Press. 
Bean C and Papadakis E (1998a) A comparison of mass attitudes towards the welfare state in different institutional regimes, 1985-1990. International Journal of Public Opinion Research 10(3): 211-236.

Bean C and Papadakis E (1998b) A comparison of mass attitudes towards the welfare state in different institutional regimes, 1985-1990. 10: 15-16.

Black R, Engbersen G, Okólski M, et al. (2012) A Continent Moving West?: EU Enlargement and Labour Migration from Central and Eastern Europe. Amsterdam: Amsterdam University Press.

Blekesaune M and Quadagno J (2003) Public Attitudes toward Welfare State Policies: A Comparative Analysis of 24 Nations. European Sociological Review 19(5): 415-427.

Bryson C (1997) Benefit Claimants: Villains or Victims? In: Jowell R, Curtice J, Park A, et al. (eds) British Social Attitudes: The 14th Report. Aldershot: Ashgate, pp. 73-88.

Busemeyer MR, Goerres A and Weschle S (2009) Attitudes towards redistributive spending in an era of demographic ageing: the rival pressures from age and income in 14 OECD countries. Journal of European Social Policy 19(3): 195-212.

Cook LJ (2007) Postcommunist Welfare States: Reform Politics in Russia and Eastern Europe. Ithaca, United States: Cornell University Press.

Coughlin RM (1980) Ideology, Public Opinion \& Welfare Policy: Attitudes towards Taxes and Spending in Industrialized Societies. Berkeley: Institute of International Studies, University of California.

Dallinger U (2010) Public support for redistribution: What explains cross-national differences? Journal of European Social Policy 20(4): 333-349. 
Deacon B (2000) Eastern European welfare states: the impact of the politics of globalization. Journal of European Social Policy 10(200005): 146-161.

Denisenko M, Strozza S and Light M (2020) Migration from the Newly Independent States: 25 Years after the Collapse of the USSR. Cham, Switzerland: Springer.

Dion ML and Birchfield V (2010) Economic Development, Income Inequality, and Preferences for Redistribution. International Studies Quarterly 54(2): 315-334.

Eardley T and Matheson G (1999) Australian attitudes to unemployment and unemployed people. SPRC Discussion Paper Series 102. Available at: http://library.bsl.org.au/jspui/bitstream/1/303/1/SPRC Discussion Paper No 102.pdf (accessed 6 June 2017).

Edlund J (1999) Trust in government and welfare regimes: Attitudes to redistribution and financial cheating in the USA and Norway. European Journal of Political Research 35(3): $341-370$.

Fajth G (1999) Social Security in a Rapidly Changing Environment: The Case of the Postcommunist Transformation. Social Policy and Administration 33(4): 416-436.

Falkingham J and Vlachantoni A (2010) Pensions and Social Protection in Central Asia and South Caucasus: Developments in the Post-Soviet era. University of Southampton. Available at: https://eprints.soton.ac.uk/173811/.

Ferge Z (1997) The changed welfare paradigm: The individualization of the social. Social Policy and Administration 31(1): 20-44. DOI: 10.1111/1467-9515.00035.

Finseraas H (2009) Income inequality and demand for redistribution: A multilevel analysis of European public opinion. Scandinavian Political Studies 32(1): 94-119. 
Fraile M and Ferrer M (2005) Explaining the Determinants of Public Support for Cuts in Unemployment Benefits Spending across OECD Countries. International Sociology 20(4): 459-481.

Gallie D and Paugam S (2002) Social Precarity and Social Integration. Report for the European Commission Based on Eurobarometer 56.1. Available at: http://ec.europa.eu/commfrontoffice/publicopinion/archives/ebs/ebs_162_en.pdf (accessed 3 March 2019).

Gebel M (2008) Labour markets in Central and Eastern Europe. In: Kogan I, Gebel M, and Noelke C (eds) Europe Enlarged: A Handbook of Education, Labour and Welfare Regimes in Central and Eastern Europe. Bristol: The Policy Press.

Groskind F (1994) Ideological influences on public support for assistance to poor families. Social Work 39(1): 81-89.

Gugushvili D (2017) The evolution of the Georgian social protection system since independence: An unclear future despite recent expansion. International Social Security Review 70(1): 51-77.

Gugushvili D (2018) Public attitudes towards the poor in the South Caucasus: a matter of solidarity and conditionality. International Journal of Sociology and Social Policy 38(56): $426-443$.

Habibov N (2013) Who Wants to Redistribute? An Analysis of 14 Post-Soviet Nations. Social Policy and Administration 47(3): 262-286.

Hacker B (2009) Hybridization instead of clustering: Transformation processes of welfare policies in Central and Eastern Europe. Social Policy and Administration 43(2): 152 
169.

Hasenfeld Y and Rafferty JA (1989) The determinants of public attitudes toward the welfare state. Social Forces 67(4): 1027-1048.

Hills J (2002) Following or Leading Public Opinion? Social Security Policy and Public Attitudes since 1997. Fiscal Studies 23(4): 539-558. DOI: 10.1111/j.14755890.2002.tb00072.x.

ILO (2017) World Social Protection Report 2017-2019: Universal Social Protection to Achieve the Sustainable Development Goals. Geneva: ILO.

Jæger MM (2006) What makes people support public responsibility for welfare provision: Self-interest or political ideology? A longitudinal approach. Acta Sociologica 49(3): $321-338$.

Jæger MM (2013) The effect of macroeconomic and social conditions on the demand for redistribution: A pseudo panel approach. Journal of European Social Policy 23(2): 149163.

Jeene M, van Oorschot W and Uunk W (2014) The dynamics of welfare opinions in changing economic, institutional and political contexts: An empirical analysis of Dutch deservingness opinions, 1975-2006. Social Indicators Research 115(2): 731-749.

Jordan J (2013) Policy feedback and support for the welfare state. Journal of European Social Policy 23(2): 134-148.

Manning N (2004) Diversity and change in pre-accession Central and Eastern Europe since 1989. Journal of European Social Policy 14(3): 211-232. DOI:

$10.1177 / 0958928704044620$. 
Mitchell A. Orenstein (2008) Postcommunist Welfare States. Journal of Democracy 19(4): 80-94. DOI: $10.1353 /$ jod.0.0038.

Noelke C (2008) Social protection, inequality and labour market risks in Central and Eastern Europe. In: Kogan I, Gebel M (Michael), and Noelke C (eds) Europe Enlarged : A Handbook of Education, Labour and Welfare Regimes in Central and Eastern Europe. Bristol: Policy Press, pp. 63-95.

Orenstein M (2008) Postcommunist Welfare States. Journal of Democracy 19(4): 80-94.

Reeskens T and van der Meer T (2019) The inevitable deservingness gap: A study into the insurmountable immigrant penalty in perceived welfare deservingness. Journal of European Social Policy 29(2): 166-181. DOI: 10.1177/0958928718768335.

Rodríguez G and Elo I (2003) Intra-class correlation in random-effects models for binary data. The Stata Journal 3(1): 32-46. Available at: http://ageconsearch.tind.io//bitstream/116030/2/sjart_st0031.pdf.

Roosma F, Van Oorschot W and Gelissen J (2016) The Achilles' Heel of Welfare State Legitimacy: Perceptions of Overuse and Underuse of Social Benefits in Europe. Journal of European Public Policy 23(2). Taylor \& Francis: 177-196. DOI: 10.1080/13501763.2015.1031157.

Schmidt-Catran AW (2016) Economic inequality and public demand for redistribution: Combining cross-sectional and longitudinal evidence. Socio-Economic Review 14(1): 119-140. DOI: 10.1093/ser/mwu030.

Sihvo T and Uusitalo H (1995) Attitudes towards the welfare state have several dimensions. Scandinavian Journal of Social Welfare 4(4): 215-223. 
Svallfors S (1997) Worlds of Welfare and Attitudes to Redistribution: A Comparison of Eight Western Nations. European Sociological Review 13(3): 283-304.

Tavits M and Letki N (2009) When Left Is Right: Party Ideology and Policy in PostCommunist Europe. American Political Science Review 103(04): 555-569.

Taylor-Gooby P (1985) Public Opinion, Ideology and State Welfare. London: Routledge and Kegan Paul.

UNDP (2016) Human Development Report 2016: Human Development for Everyone. Available at: http://hdr.undp.org/sites/default/files/2016_human_development_report.pdf (accessed 24 November 2017).

van Oorschot W (2006) Making the difference in social Europe: deservingness perceptions among citizens of European welfare states. Journal of European Social Policy 16(1): $23-42$.

van Oorschot W and Gugushvili D (2019) Retrenched, but still desired? Aspects of the social legitimacy of the welfare state in Russia compared to the EU countries. Europe - Asia Studies 71(3): 345-364.

van Oorschot W, Reeskens T and Meuleman B (2012) Popular perceptions of welfare state consequences: A multilevel, cross-national analysis of 25 European countries. Journal of European Social Policy 22(2): 181-197. Available at: http://journals.sagepub.com/doi/10.1177/0958928711433653.

van Oorschot W, Roosma F, Meuleman B, et al. (2017) The Social Legitimacy of Targeted Welfare: Attitudes to Welfare Deservingness. Cheltenham: Edward Elgar. 
Wengle S and Rasell M (2008) The monetisation of l'goty: Changing patterns of welfare politics and provision in Russia. Europe-Asia Studies 60(5): 739-756.

World Bank (2018) World Bank Development Indicators. Available at: http://data.worldbank.org/ (accessed 28 August 2017). 